\title{
Manajemen Risiko Tradisi Kirab Pusaka Malam 1 Suro Keraton Surakarta
}

\author{
Yohana Maya Lalita \\ Sekolah Tinggi Pariwisata Ambarrukmo Yogyakarta \\ maya_lalita@yahoo.co.id
}

\begin{abstract}
Abstrak
Jurnal ilmiah ini menganalisis manajemen risiko dalam tradisi kirab pusaka Malam 1 Suro di Keraton Surakarta, Jawa Tengah. Tradisi ini memiliki nilai-nilai keunggulan yang sesuai dengan Pancasila serta memiliki relasi dengan alam. Tetapi, tradisi ini juga rentan terhadap ancaman bencana fisik maupun nonfisik, sehingga membutuhkan manajemen risiko yang baik untuk mengatasi masalah ini. Penulis menggunakan metode kualitatif dengan wawancara dan studi pustaka. Strategi manajemen risiko terkait dengan pengelolaan dan pelestarian bisa melibatkan banyak pihak. Respons berbagai pihak sangat dibutuhkan dalam menanggulangi risiko tersebut. Selain itu, ada potensi yang ditemukan untuk mengembangkan manajemen tradisi ini dan berdampak untuk ekonomi yang berkelanjutan
\end{abstract}

Kata kunci: manajemen risiko, tradisi, budaya

\begin{abstract}
This scientific journal analyzes the risk management in Malam 1 Suro heritage procession in Surakarta Palace, Central Java. This tradition has values of excellence that are in accordance with Pancasila values and it has relations with nature. However, this tradition is also vulnerable to the threat of physical and non-physical disasters so it requires good risk management to overcome this problem. The author uses qualitative methods with making interviews and literature. Risk management strategies related to management and preservation can involve many divisions. The response of various divisions is needed in overcoming these risks. In addition, there is a potentiality which is found in developing the management of this tradition and it has an impact on a sustainable economy.
\end{abstract}

Keywords: risk management, tradition, culture

\section{PENDAHULUAN}

Warisan budaya tak benda atau yang biasa juga disebut intangible cultural heritage, berarti praktik, representasi, ungkapan, pengetahuan, keterampilan - serta instrumen, benda, artefak, dan ruang budaya yang terkait dengannya - bahwa masyarakat, kelompok dan, dalam beberapa kasus, individu mengakui sebagai bagian dari warisan budaya mereka. Menurut Konvensi Pelestarian Warisan Budaya Tak Benda tahun 2003, warisan budaya tak benda (intangible cultural heritage- $\mathrm{ICH}$ ) - atau warisan hidup adalah sumber utama keragaman budaya umat manusia dan pemeliharaannya merupakan jaminan untuk melanjutkan kreativitas. "Sementara warisan budaya global berkaitan dengan perlindungan warisan budaya yang dibuat manusia, nyata, dan fisik, perhatian 
utama dari ICH adalah unsur-unsur nonfisik seperti roh, kesenian, dan kreativitas yang ada sebagai bentuk ekspresi artistik atau budaya. Hal ini dapat dilihat untuk dirinya sendiri memiliki nilai estetik, nilai teknis, dan nilai artistik, tetapi juga sangat mudah menghilang di bawah pengaruh pemikiran modern karena mereka adalah kenangan di tingkat spiritual." (Yue Zhang, Mingqing Han, and Weiwei Chen, 2018, p. 2)

Dengan memelihara warisan budaya tak benda ini maka akan melestarikan alam semesta dan kehidupan di dalamnya. Hal ini penting sebagai usaha untuk mengukir sejarah bagi masa depan. Selain itu, dengan dilestarikannya warisan budaya ini, maka setiap negara akan memiliki identitasnya masing-masing. Keberagaman akan terus berlangsung dan toleransi akan tetap dipertahankan. Warisan budaya tak benda ini, yang ditransmisikan dari generasi ke generasi, terus diciptakan oleh masyarakat dan kelompok dalam menanggapi lingkungan mereka, interaksi mereka dengan alam dan sejarah, dan memberi mereka rasa identitas dan kontinuitas, sehingga meningkatkan rasa hormat terhadap keragaman budaya dan kreativitas manusia. Untuk tujuan konvensi ini, pertimbangan hanya diberikan untuk warisan budaya tak benda seperti yang sesuai dengan instrumen hak asasi manusia internasional yang ada, serta dengan persyaratan saling menghormati di antara masyarakat, kelompok dan individu, dan pengembangan berkelanjutan.

Semua warisan budaya, apakah itu artefak, monumen, situs arkeologi, tempattempat suci, lanskap budaya, ruang alam, ekspresi berwujud atau spesies yang terancam dalam ekosistem unik mereka, satu adalah, untuk derajat yang berbeda dan dengan cara yang berbeda, rentan terhadap risiko yang diciptakan oleh manusia dan alam. Risiko tersebut termasuk perubahan lingkungan dan iklim, serta yang timbul dari konflik, vandalisme, penjarahan, atau penelantaran.

Tradisi Kirab Pusaka Malam 1 Suro layak dikategorikan sebagai warisan budaya tak benda meskipun belum ada pengakuan secara resmi dari pihak UNESCO maupun dari lembaga negara. Alasannya adalah karena tradisi tersebut mengandung nilai-nilai asli yang universal dan berelasi dengan alam. Maka pelestarian dan keberlanjutannya penting untuk dilaksanakan semua pihak. Pelestarian dan keberlangsungan suatu tradisi sangat terkait dengan manajemen risiko, dalam hal ini khususnya bidang tradisi, ritual, dan kebudayaan.

Risiko ancaman fisik dan nonfisik pada tradisi ini masih kurang diperhatikan. Terlihat dari adanya dua kasus yang terjadi pada bulan November 2014 lalu, ada berita terkait matinya seekor kerbau bule keturunan Kiai Slamet milik Keraton Kasunanan Surakarta akibat tertusuk tombak di bagian perut dan kaki. Kemudian melihat ke belakang, pada 2011, kandang kerbau bule Kiai Slamet milik keraton juga dipasangi bom menjelang peringatan Malam 1 Suro. Motif pelaku penusukan dan pemasang bom tersebut tidak ditemukan dalam pencarian di internet. Namun apapun yang mendasari kedua kasus di atas, tetap merupakan ancaman bencana nonfisik bagi pusaka di Keraton Surakarta, khususnya tradisi Kirab Pusaka Malam 1 Suro.

Maka identifikasi risiko ancaman bencana fisik maupun nonfisik beserta manajemen risikonya menjadi penting. Termasuk di dalamnya ada upaya menggali potensi pendukung tradisi tersebut untuk mengembangkan keberlanjutan ekonomi masyarakat sekitar. 


\section{METODE PENELITIAN}

Penelitian ini menggunakan pendekatan kualitatif, yaitu strategi dan teknik penelitian yang digunakan untuk memahami masyarakat, masalah atau gejala dalam masyarakat dengan mengumpulkan sebanyak mungkin fakta mendalam, data disajikan dalam bentuk verbal bukan dalam bentuk angka. Pendekatan ini digunakan penulis dikarenakan subjek kajian penelitian ini adalah manajemen risiko tradisi Kirab Pusaka Malam 1 Suro Keraton Surakarta yang bisa diuraikan dalam bentuk narasi.

Dalam mengungkap semua fenomena dan makna secara alamiah tersebut, penulis menggunakan metode deskriptif. Dalam hal ini penulis akan mendeskripsikan tentang kondisi objektif manajemen risiko tradisi Kirab Budaya Malam 1 Suro Keraton Surakarta. Jenis penelitian ini menggunakan metode penelitian deskriptif evaluatif. Penelitian deskriptif memiliki beberapa hal yang dapat dideskripsikan pada hasil penelitian, yakni menggambarkan, menjelaskan, menganalisis, ataupun mengevaluasi hasil kegiatan penelitian.

Narasumber yang telah diwawancara terkait dengan penelitian ini adalah:

1. K.R.A.T. Tejo Bagus Sunaryo, S.Sn., MA. selaku abdi dalem Keraton Surakarta.

2. Nyi Behi Panggih Pratiwi selaku abdi dalem Keraton Surakarta.

3. Pak Narso selaku abdi dalem Keraton Surakarta dan staf Museum Keraton Surakarta.

Guna memperoleh data yang akurat dalam penelitian ini, penulis menggunakan prosedur pengumpulan data. Dalam pengumpulan data penelitian, teknik yang umum dipakai yaitu: wawancara. Dengan wawancara, maka penulis akan mengetahui hal-hal yang lebih mendalam tentang partisipan dalam menginterpretasikan situasi dan fenomena yang terjadi, di mana hal ini tidak bisa ditemui melalui observasi. Adapun wawancara yang penulis gunakan adalah wawancara langsung dengan tatap muka dengan cara tidak terstruktur. Teknik ini penulis perlukan untuk menggali data tentang fokus penelitian.

Wawancara di samping berfungsi sebagai pengumpul data, juga akan memperdalam pengetahuan penulis tentang objek yang diteliti. Setelah data mentah didapatkan, penulis kemudian menganalisis data tersebut dan menandai informasi sesuai dengan kategorinya.

\section{PEMBAHASAN}

\section{Sejarah Malam 1 Suro}

Malam 1 Suro dalam masyarakat Jawa adalah suatu perayaan tahun baru menurut kalender Jawa. Dalam perhitungan Jawa, malam 1 Suro dimulai dari terbenamnya matahari pada hari terakhir bulan terakhir kalender Jawa (29/30 bulan Besar) sampai terbitnya sang matahari pada hari pertama bulan pertama tahun berikutnya. Di kalangan Keraton Yogyakarta dan Kasunanan Surakarta, bulan Suro dimaknai sebagai yang suci atau bulan penuh rahmat. Artinya, pada bulan Suro orang harus melakukan introspeksi 
diri, manekung, dan melakukan laku maladihening atau mendekatkan diri dengan Tuhan Yang Maha Esa.

Pada masa Pemerintahan Pakoe Boewono II, zaman Keraton Kartasura di sekitar abad ke-17, diceritakan bahwa di kerajaan terjadi pemberontakan yang dilakukan oleh Pangeran Mangkubumi yang membuat Sinuwun harus melarikan diri ke Ponorogo. Di Ponorogo beliau ditampung oleh Bupati Ponorogo dan berdiam di sana untuk beberapa saat hingga pemberontakan berakhir. Pada masa pelariannya di Ponorogo, Raja Kartasura itu memperoleh petunjuk gaib bahwa pusaka Kyai Slamet harus direkso atau dijaga oleh sepasang kebo bule atau kerbau albino jika ingin kerajaan aman sentosa dan langgeng.

Kuasa Tuhan yang luar biasa pada saat itu, Bupati Ponorogo tiba-tiba ingin menunjukkan baktinya kepada rajanya dengan mempersembahkan sepasang kebo bule kepada Sinuwun, tepat di saat beliau membutuhkannya. Kebo bule atau kerbau albino pada masa itu (mungkin juga pada masa sekarang) adalah kerbau yang sangat jarang ditemui dan dimiliki orang kebanyakan dan merupakan hewan piaraan bernilai tinggi. Maka Sinuwun Pakoe Boewono II menerima dengan baik pisungsung (persembahan) dari Bupati Ponorogo dan berterima kasih atas persembahan yang sangat sesuai dengan kebutuhannya. Sinuwun membawa sepasang kebo bule itu kembali ke Keraton Kartasura setelah pemberontakan usai dan hingga kerajaan berpindah tempat ke Desa Sala dan berganti nama menjadi Keraton Surakarta Hadiningrat. Hingga kini kerbau Kyai Slamet telah beranak pinak dan tetap dihormati dan disebut sebagai kebo bule Kyai Slamet. Konon, saat Pakoe Buwono II mencari lokasi untuk keraton yang baru, tahun 1725, leluhur kebo-kebo bule tersebut dilepas, dan perjalanannya diikuti para abdi dalem keraton, hingga akhirnya berhenti di tempat yang kini menjadi Keraton Kasunanan Surakarta.

Selain Keraton Surakarta, Keraton Yogyakarta juga mengadakan ritual serupa. Namun banyak perbedaan yang terjadi di dalamnya. Perbedaan tersebut antara lain terletak pada kerbau albino, yang di Keraton Surakarta sebagai cucuk lampah kirab pusaka. Kemudian peserta kirab pusaka yang di Keraton Yogyakarta boleh diikuti masyarakat awam.

\section{Nilai-nilai dan Keunggulan}

Berdasarkan Peraturan Menteri Pendidikan dan Kebudayaan Republik Indonesia Nomor 106 Tahun 2013 Tentang Warisan Budaya Tak Benda Indonesia Pasal 2 mengatur bahwa Warisan Budaya Tak Benda Indonesia harus berasaskan:
a. Pancasila;
b. Undang-Undang Dasar Negara Republik Indonesia Tahun 1945;
c. Bhinneka Tunggal Ika;
d. Negara Kesatuan Republik Indonesia; dan
e. transparansi dan akuntabilitas.

Keunggulan pada Kirab Pusaka Malam 1 Suro milik Keraton Surakarta mengandung ritual yang sesuai dengan nilai-nilai Pancasila sehingga bisa diadaptasi sebagai pusaka milik negara (nasional). Pancasila telah menjadi ideologi dasar dalam kehidupan berbangsa dan bernegara di Indonesia. Dalam ritual ini diharapkan masyarakat dapat menghidupi nilai sila pertama, yaitu Ketuhanan Yang Maha Esa. Hal ini bisa dilihat 
dan dirasakan pada saat kirab pusaka. Para abdi dalem yang memiliki keyakinan berbedabeda tetap mengikuti refleksi dan berdoa bersama di ritual ini.

Sila kedua, kemanusiaan yang adil dan beradab, digambarkan dalam aturan Keraton Surakarta yaitu menjunjung tinggi nilai-nilai kesopanan. Selain itu, keadilan juga terdapat pada aturan dalam ritual tersebut yaitu bahwa para abdi dalem dilarang memakai kepangkatannya, sehingga semua abdi bahkan keluarga raja terlihat sama. Pakaian bagi para pembawa pusaka juga diatur sedemikian rupa yaitu pakaian adat Jawa jangkep (lengkap) dan wajib mengenakan kalung (kain) samir serta untaian bunga melati (gajah ngoling) di atas telinga kiri.

Pada sila ketiga yaitu Persatuan Indonesia, digambarkan dengan berkumpulnya para abdi dalem dari suku dan asal yang berbeda-beda. Tidak hanya abdi dalem, namun masyarakat sekitar dan juga para wisatawan ikut berkumpul dan bersatu selama ritual ini berlangsung. Sehingga ritual ini juga mempersatukan masyarakat dari berbagai kalangan.

Sedangkan sila keempat yaitu, kerakyatan yang dipimpin oleh hikmat kebijaksanaan dalam permusyawaratan/perwakilan, sesuai dengan nilai-nilai yang ada dalam pengambilan keputusan di Keraton Surakarta. Pembentukan kepanitiaan dan pengelolaan ritual ini adalah berdasarkan musyawarah dan mufakat bersama.

Kembul bujana atau makan bersama merupakan bagian dari tradisi kirab pusaka ini menggambarkan sila kelima yaitu keadilan sosial bagi seluruh rakyat Indonesia. Selain itu, keadilan sosial juga menjadi salah satu doa dan harapan yang dipanjatkan terusmenerus dalam ritual ini.

Menurut Suryo (tanpa tahun: 247), Sri Susuhunan Pakubuwono XII pernah bersabda bahwa Kirab Pusaka 1 Suro di Surakarta diadakan dengan harapan untuk membantu rakyat supaya hidup selamat, damai, makmur, atas perkenanan Tuhan Yang Maha Kuasa.

Tradisi Kirab Pusaka Malam 1 Suro di Keraton Surakarta ini memiliki nilai-nilai yang dapat dimaknai sebagai berikut:

- Mahesa/Kerbau Albino: sebagai simbol kesuburan dunia.

- Pusaka: sebagai simbol kekuatan dari Ilahi.

- Tapa Mbisu: kolektivitas ritual (laku) doa bermakna introspeksi diri.

Esensi atau makna dari kirab pusaka tersebut adalah pertobatan, doa, dan pengharapan untuk tahun depan supaya senantiasa subur (gemah ripah loh jinawi) yang disimbolkan dengan kerbau albino (mahesa), selamat, teguh, dan tenteram yang disimbolkan dengan meng-kirab pusaka. Kirab pusaka mengelilingi benteng luar Keraton Surakarta menggambarkan mikro kosmos dan makro kosmos. Mikro kosmos adalah sebagai refleksi diri sendiri. Dan makro kosmos maksudnya ialah keraton (buwana) merupakan representasi dari dunia/jagad gedhe.

\section{Relasi dengan Alam dan Budaya}

a. Kotoran kerbau sebagai pupuk yang baik bagi lahan pertanian.

b. Menjaga kelestarian kerbau albino sebagai hewan yang langka.

c. Tata kota akan tetap lestari karena rute kirab akan sama dari tahun ke tahun. Prosesi kirab pusaka berangkat dari halaman keraton (Kamandungan). Setelah melewati alun-alun utara, sampai di gapura Gladak belok ke kanan. Sampai perempatan Sangkrah 
belok ke kanan menyusuri Jalan Kapten Mulyadi, sampai di perempatan Baturana belok ke kanan masuk Jalan Veteran. Sampai di perempatan Gamblengan belok ke kanan, ke utara melalui Jalan Keratonan hingga perempatan Nonongan. Dari perempatan Nonongan belok ke kanan menyusuri Jalan Slamet Riyadi hingga perempatan Gladak. Dari perempatan Gladak belok ke kanan masuk alun-alun utara, dan kembali ke halaman keraton. Pada prinsipnya, kirab pusaka itu mengikuti arah pradaksina (menganankan) Karaton. (Rustopo, 2008:197)

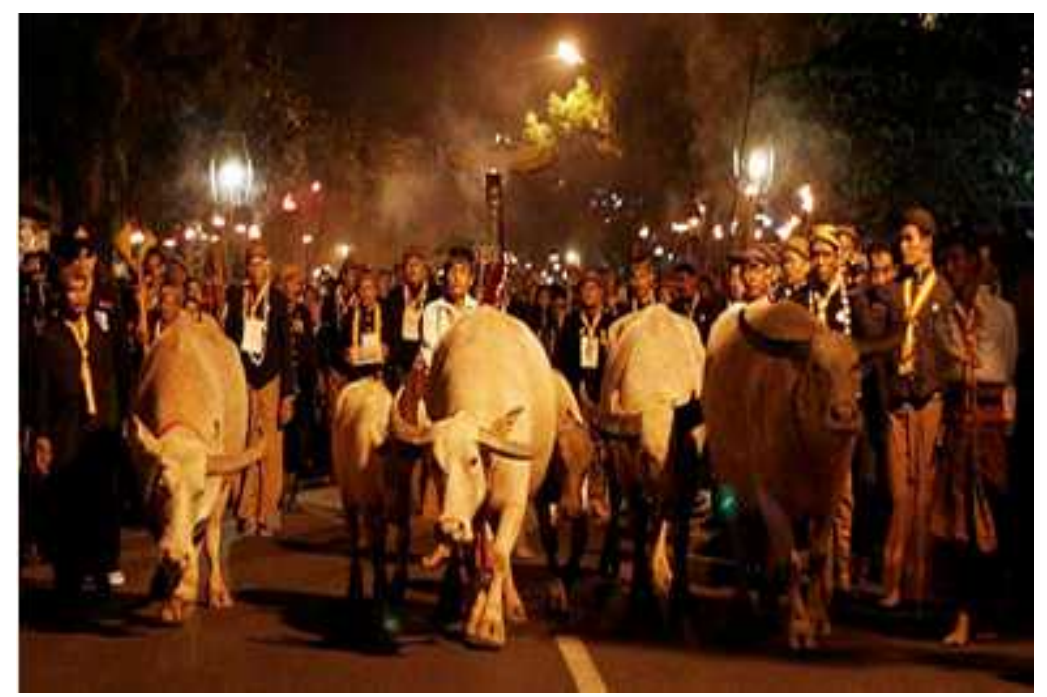

Gambar 1. Kirab Pusaka Malam 1 Suro Keraton Surakarta

Sumber:https://www.google.co.id/search?q=kirab+pusaka+malam+1+Suro+di+kerat on + Surakarta\&source $=1 \mathrm{nms} \&$ tbm $=\mathrm{isch} \& \mathrm{sa}=\mathrm{X} \&$ ved $=0$ ahUKEwiszLS0sY7YAhWL oZQKHcDLCYAQ_AUICigB\&biw=1366\&bih=651\#imgdii=cLa5kiHsS4qiQM:\&i mgrc $=$ vNdFIUByHUqlzM:

d. Kegotongroyongan semua manusia (rasa, rumangsa, lan ngrumangsani) karena pada saat acara tersebut para sentana maupun abdi dalem tidak diperkenankan memakai tanda kepangkatan pada pakaiannya (ageman).

\section{Prosesi Kirab Pusaka}

1. Berdoa Bersama (Umbul Donga)

Waktu: setelah Isya $(19.30$ - 22.00) WIB

Isi: Sholawatan dan tahlil (secara islam).

2. Suara Gamelan

Waktu: 22.00 - 23.00 WIB

Ladrang wilujeng kendangan engkek Pakubuwanan.

Sementara di luar kori kamandungan, abdi dalem menyiapkan barisan kerbau albino (mahesa). 


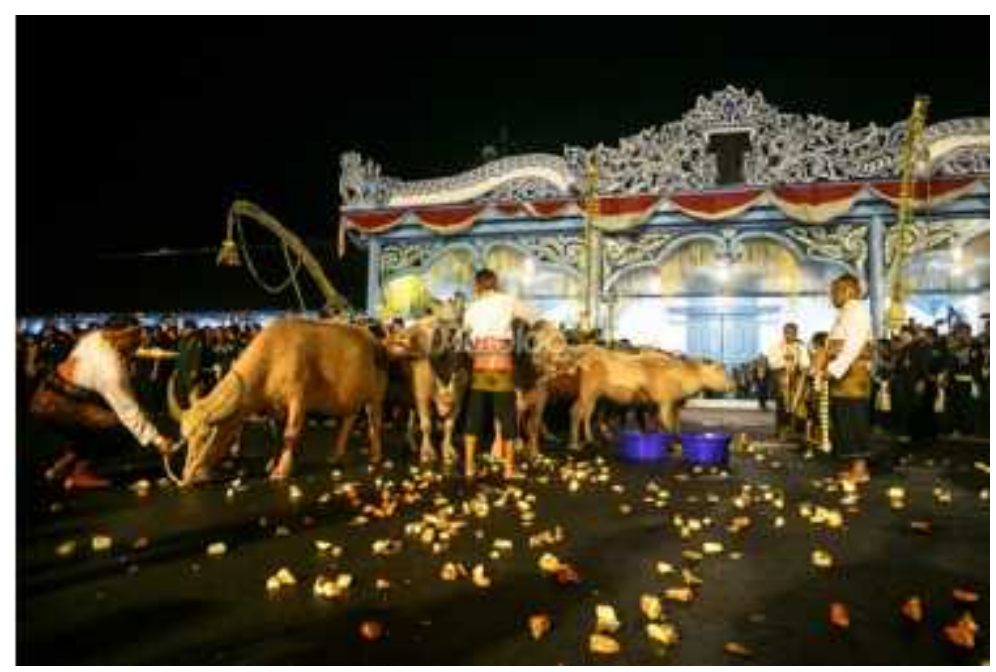

Gambar 2. Para abdi dalem Keraton Surakarta mempersiapkan barisan kerbau albino (mahesa) di depan Kamandungan.

Sumber:https://www.google.co.id/search?biw=1366\&bih=651\&tbm=isch\&sa=1\&ei=3f00Wp6 6L9HX0gTf7oDoBQ\&q=kirab+pusaka+malam+1+Suro\&oq=kirab+pusaka+malam+1+Suro\& gs_l=psyab.3..0i24k1.117500.117500.0.117850.1.1.0.0.0.0.161.161.0j1.1.0.......1c.1.64.psyab.

.0.1.160...0.jPUp_HoPHg4\#imgdii=7emBnob4x1ws0M:\&imgrc=P1tCbUsaBnMxXM

3. Kirab Pusaka Keliling Benteng Luar Keraton Surakarta

Waktu: 23.00 - 02.00 WIB

4. Makan Bersama di Keraton (Kembul Bujono)

Waktu : $02.00-03.00 \mathrm{WIB}$

\section{Pengelolaan dan Pelestarian}

a. Pengelolaan: Keraton Surakarta memiliki panitia khusus yang terdiri dari gabungan panitia internal keraton dengan perwakilan dari pemerintah. Saat ini pendanaan acara ritual di Keraton Surakarta sudah dibantu oleh pemerintah.

b. Pelestarian: Kirab Pusaka Malam 1 Suro ini telah menjadi agenda tahunan di Kota Surakarta. Acara ini wajib diselenggarakan setiap tahunnya dan telah menjadi ikon Kota Surakarta.

\section{Identifikasi Risiko Kerentanan terhadap Bencana}

Maria Susana Pataro telah menyebut risiko buatan manusia sebagai entropi, terjadi dalam dimensi yang berbeda, yang dapat dikaitkan dengan hal-hal berikut:

(1) pembangunan: tekanan ekonomi, pembangunan perkotaan, pekerjaan umum besar, pariwisata yang tidak terkendali, polusi, pembangunan taman tematik yang mengancam keaslian situs dll.;

(2) bentuk-bentuk perilaku tertentu seperti vandalisme, pencurian, kerusuhan, konflik etnis, perang, serangan teroris. Dalam kasus kawasan yang dilindungi secara alami, pengenalan spesies eksotis, pemukiman manusia, perburuan spesies yang terancam punah, pengenalan pestisida atau pupuk, dll.; 
(3) kesenjangan dalam kebijakan konservasi seperti legislasi yang tidak memadai, kurangnya pelatihan dan etika profesional, perubahan status hukum yang melindungi situs tertentu, tidak adanya warisan dalam agenda politik.

Dalam kasus ini, ritual Kirab Pusaka Malam 1 Suro di Keraton Surakarta ini sangat rentan dengan kategori risiko poin (2) yaitu bentuk perilaku tertentu serta terorisme, dan poin (3) kebijakan konservasi serta status hukum yang melindunginya. Berikut kemungkinan-kemungkinan bencana nonfisik yang bisa terjadi, yaitu:

1. Perilaku aliran keagamaan garis keras yang menolak pemahaman terkait tradisi ini.

2. Adanya kesalahpahaman masyarakat untuk mengerti maupun memahami nilai-nilai dari ritual ini. Informasi yang didapatkan dari salah satu abdi dalem Museum Keraton Surakarta bahwa motif pelaku penombakan dan teror bom di area Keraton Surakarta diduga termasuk dalam kategori ini. Kasus ini cukup meresahkan, mengingat kerbau albino adalah hewan yang langka. Jika tidak direspons dengan edukasi yang benar dan dapat diterima logika oleh masyarakat, maka hal ini akan menjadi bumerang bagi ritual Kirab Pusaka Malam 1 Suro tersebut.

3. Pengaruh citra keluarga istana. Keributan atau persengketaan yang terjadi pada internal keraton. Seperti kasus yang lalu, ketika keributan internal itu terekspos ke publik maka, akan terjadi penurunan kepercayaan dari publik terhadap kewibawaan Keraton Surakarta sebagai pemangku adat utama di wilayah Jawa Tengah. Masyarakat dan calon wisatawan akan kehilangan minat untuk berkunjung ke keraton. Publik tidak lagi memandang Keraton Surakarta beserta keluarganya sebagai teladan dan stigma negatif akan melekat cukup lama pada keraton maupun keluarga keraton itu sendiri. Butuh waktu dan proses yang panjang untuk memperbaiki stigma negatif tersebut dan mengembalikan kepercayaan publik kepada Keraton Surakarta.

4. Kebijakan pelestarian pemerintah dan perlindungan hukum. Saat ini belum ada pengaturan kebijaksanaan pelestarian khusus dan upaya perlindungan hukum terhadap tradisi ini. Bahkan tradisi ini belum terakui secara resmi oleh UNESCO maupun negara sebagai warisan dunia.

5. Selain bencana nonfisik, juga perlu diwaspadai bencana fisik seperti masalah kesehatan dan kecukupan gizi kerbau albino milik Keraton Surakarta. Kerbau albino ini merupakan hewan yang langka sehingga penanganan sekaligus perawatannya harus benar-benar diperhatikan. Jika terjadi wabah penyakit hewan atau hewan tersebut terkena suatu penyakit tertentu, maka kerbau albino ini akan terancam kepunahannya.

\section{Strategi Manajemen Risiko}

Setelah mengidentifikasi berbagai kemungkinan risiko kerentanan terhadap bencana fisik maupun nonfisik, maka ada beberapa rekomendasi mengenai upaya yang bisa dilakukan untuk merespons berbagai risiko tersebut.

1. Sesuai dengan Peraturan Menteri Pendidikan dan Kebudayaan RI No. 106 Tahun 2013 Tentang Warisan Budaya Tak Benda Indonesia Bab V bisa dilakukan penetapan terhadap tradisi ini.

Penetapan Warisan Budaya Takbenda Indonesia bertujuan:

a. melestarikan Warisan Budaya Tak Benda Indonesia;

b. meningkatkan harkat dan martabat bangsa; 
c. memperkuat karakter, identitas, dan kepribadian bangsa;

d. mempromosikan Warisan Budaya Tak Benda Indonesia kepada masyarakat luas; dan;

e. meningkatkan kesejahteraan rakyat.

Kemudian dapat diusulkan sebagai pusaka nasional, alasannya adalah karena ritual ini memiliki keaslian, keunikan, dan nilai-nilai yang unggul dalam setiap prosesinya. Nilai-nilai dan keunggulan yang dimiliki tradisi tersebut juga telah dianalisis dan sesuai dengan nilai-nilai Pancasila sebagai dasar negara Indonesia. Kemudian supaya memiliki pengakuan resmi dan kekuatan hukum sebagai perlindungan terhadap tradisi ini.

2. Sesuai dengan Peraturan Menteri Pendidikan dan Kebudayaan RI Nomor 10 Tahun 2014 Tentang Pedoman Pelestarian Tradisi dalam Bagian Keempat Pengembangan Pasal 8 angka 2 (c) Pengembangan tradisi dilakukan melalui: diskusi, seminar, dan sarasehan pengembangan tradisi dan pembinaan karakter dan pekerti bangsa; sehingga dapat melakukan proses edukasi terhadap masyarakat luas terkait nilai-nilai yang terkandung dalam tradisi tersebut. Sebaiknya topik terkait ritual budaya ini diangkat menjadi topik khusus di seminar tentang kebudayaan setiap tahunnya. Kemudian relasi antara internal dan pemerintah bisa ditambahkan dengan pihak akademisi dalam bidang kebudayaan sebagai peneliti maupun pengkaji ritual tersebut.

3. Pelestarian dan edukasi juga bisa melibatkan seniman dengan cara menggelar drama musikal maupun teatrikal yang menceritakan sejarah Kirab Pusaka Malam 1 Suro dari berbagai versi. Hal ini penting sebagai sarana edukasi bagi masyarakat melalui seni juga sebagai daya tarik pertunjukan bagi wisatawan yang berkunjung. Drama musikal maupun teatrikal ini akan melibatkan banyak pihak dan juga mendukung pengembangan ekonomi di sekitar lokasi pertunjukan. Rencana jangka panjang konsep drama dan teatrikal ini bisa diperlombakan antar-instansi maupun di tingkat pendidikan. Lalu selanjutnya bisa menjadi festival khas di bulan Suro.

4. Terkait citra keluarga istana, cara yang bisa dilakukan adalah membangun komunikasi yang intens antar-internal Keraton. Menentukan hierarki pengelolaan internal keraton dengan jelas dan transparan. Saat ini keputusan pemerintah terkait penetapan raja dan mahapatih sudah cukup membantu memberikan kejelasan. Kemudian melakukan koordinasi dengan pemerintah secara berkelanjutan. Memperbaiki citra dengan mengirimkan perwakilan untuk ikut serta dalam bidang kebudayaan dan seni secara konsisten.

5. Untuk merespons kemungkinan terkait kesehatan kerbau, maka dibutuhkan pengawasan kesehatan kerbau albino secara rutin dari pihak pemerintah, akademisi kesehatan hewan, maupun pihak internal Keraton Surakarta itu sendiri.

\section{Perencanaan Ekonomi Berkelanjutan Bagi Masyarakat}

Pelestarian tradisi hendaknya juga didukung dengan perencanaan ekonomi kreatif dan keberlanjutan dengan melihat dan menggali potensi-potensi yang ada. Penulis melihat bahwa di saat bulan Suro ada banyak momen aktivitas selamatan. Selain melaksanakan selamatan khusus pada bulan Suro, kalangan Keraton Yogyakarta dan Kasunanan Surakarta juga memiliki tradisi selamatan tiap bulan menurut penanggalan Jawa. Ritual 
sesaji ini biasanya dilaksanakan pada tanggal 8 atau hari Jumat dalam bulan Suro. Di Keraton Kasunanan Surakarta biasanya dibarengi dengan peringatan hari berdirinya Keraton Surakarta (pengetan adeging Nagari Surakarta Hadiningrat). Uborampe (kelengkapan) sesaji selamatan pada bulan Suro tersebut adalah bubur yang dicampur dengan sembilan bahan seperti kacang botor, jagung, kacang, kacang gude, biji asam, kemangi, kacang hijau, lada putih, dan biji buah delima. Kelengkapan sesaji ini dimaksudkan untuk memule (memperingati) Baginda Husain. (Wahyana, 2009:55)

Sesaji yang khas dan selalu ada pada bulan Suro ini dapat dijadikan salah satu alternatif bagi pengembangan ekonomi masyarakat di sekitar Keraton Surakarta. Masyarakat sekitar bisa menjadikan momen ini sebagai alternatif usaha pada bulan Suro untuk meningkatkan pendapatan mereka. Pemerintah bersama dengan pihak Kasunanan Surakarta bisa memberikan edukasi maupun bantuan modal terkait sesaji bulan Suro sebagai kuliner khas yang bisa dijual kepada wisatawan.

Masyarakat sekitar memerlukan edukasi tentang filosofi sesaji, proses pembuatannya, dimulai dari memasak, mengemasnya, hingga pada akhirnya sampai di tangan wisatawan. Wisatawan pun mendapatkan pengetahuan dan sesuatu yang baru dari rangkaian ritual Kirab Pusaka Malam 1 Suro ini. Ada pengalaman serta buah tangan yang baru dan unik yang bisa dibagikan kepada wisatawan domestik maupun wisatawan mancanegara.

\section{KESIMPULAN}

Dari pembahasan di atas, maka penulis dapat mengambil kesimpulan bahwa tradisi Kirab Pusaka Malam 1 Suro di Keraton Surakarta ini memiliki nilai-nilai dan keunggulan sesuai dengan Pancasila dan memiliki relasi dengan alam dan budaya.

Tradisi ini memiliki kemungkinan risiko kerentanan terhadap bencana yaitu: bentuk perilaku tertentu serta terorisme, dan kebijakan konservasi serta status hukum yang melindunginya. Dan terdapat rekomendasi sebagai upaya merespons serta mengatasi kemungkinan resiko tersebut di antaranya: dapat diusulkan menjadi Pusaka Nasional, melakukan edukasi dalam bentuk seminar, bekerja sama untuk menggelar drama teatrikal yang mengangkat tentang sejarah dan nilai tradisi tersebut, kebijakan pemerintah serta kejelasan hierarki dalam kepengurusan Keraton Surakarta, dan pengawasan kesehatan bagi kerbau albino.

Manajemen risiko melibatkan banyak pihak dan kemungkinan-kemungkinan terhadap potensi di sekitar. Pelestarian tradisi sebagai salah satu tindakan nyata manajemen risiko hendaknya juga didukung dengan perencanaan ekonomi kreatif dan keberlanjutan dengan melihat dan menggali potensi-potensi yang ada. Diusulkan menggali potensi dan filosofi berbagai sesaji yang ada sewaktu bulan Suro, salah satunya adalah sesaji bubur/jenang Suran yang bisa dikomodifikasi kemudian dijadikan alternatif kuliner bagi wisatawan dan masyarakat sekitar. 


\section{KEPUSTAKAAN}

Adewumi, Afolasade A. 2018. CULTURAL HERITAGE PROTECTION AND DISASTER RISK MANAGEMENT IN NIGERIA: Legal Framework for Promoting Coherence and Efficiency. Art Antiquity and Law, Vol. XXIII. Issue 1. 69-70.

Giri, Wahyana MC. 2009. Sajen dan Ritual Orang Jawa. Yogyakarta: Penerbit Narasi.

Moleong, Lexy J. 2006. Metodologi Penelitian Kualitatif. Bandung: Remaja Rosdakarya. Negoro, Suryo. S. _ Upacara Tradisional Jawa.

Rustopo. 2008. Jawa Sejati: Otobiografi Go Tik Swan Hardjonagoro. Yogyakarta/Jakarta: Penerbit Ombak dan Yayasan Nabil.

Zhang, Yue; Han, Mingqin; and Chen, Weiwei. 2018. "The strategy of digital scenic area planning from the perspective of intangible cultural heritage protection". Zhang et al. EURASIP Journal on Image and Video Processing, Vol. 2018 Issue 1, p1-1. 1p. DOI : 10.1186/s13640-018-0366-7.

Peraturan Menteri Pendidikan dan Kebudayaan Nomor 106 Tahun 2013 Tentang Warisan Budaya Tak Benda Indonesia.

Peraturan Menteri Pendidikan dan Kebudayaan RI Nomor 10 Tahun 2014 Tentang Pedoman Pelestarian Tradisi.

\section{INFORMAN}

K.R.A.T. Tejo Bagus Sunaryo, S.Sn., MA. (usia ... th). Abdi dalem Keraton Surakarta tinggal di ...

Nyi Behi Panggih Pratiwi (usia ... th). Abdi dalem Keraton Surakarta tinggal di ...

Pak Narso (usia ... th). Abdi dalem Keraton Surakarta dan staf Museum Keraton Surakarta tinggal di ...

\section{WEBTOGRAFI}

https://en.wikipedia.org/wiki/Intangible_cultural_heritage diakses 8 November 2017, pukul 20.00

https://ich.unesco.org/en/what-is-intangible-heritage-00003 diakses 8 November 2017, pukul 20.20

http://blog.ugm.ac.id/2010/10/28/tradisi-kirab-kerbau-kyai-slamet-pada-kirab-pusaka-1Suro-di-solo/ diakses 8 November 2017, pukul 20.50 WIB.

https://nasional.sindonews.com/read/690000/14/aksi-teror-tak-ada-untungnya-sudahisaja-1353422881

https://daerah.sindonews.com/read/920616/151/dua-pekan-kritis-ditombak-kerbau-kiaislamet-mati-1415255757

https://ich.unesco.org/en/what-is-intangible-heritage-00003 